\title{
Methods of Determination of Perspective Region's Industries as Factor of Innovational Process Intensification
}

\author{
Oksana ValerievnaVaganova $^{1}$, Sergey Nikolaevich Glagolev ${ }^{2} \&$ Svetlana Yurievna Doroshenko $^{2}$ \\ ${ }^{1}$ Belgorod State University, Belgorod, Russia \\ ${ }^{2}$ Belgorod State Technological University named after V.G. Shukhov, Belgorod, Russia \\ Correspondence: Oksana ValerievnaVaganova, Belgorod State University, Pobeda str., b.85, 308015 Belgorod, \\ Russia
}

Received: October 11,2014 Accepted: October 23, $2014 \quad$ Online Published: December 2, 2014
doi:10.5539/ass.v11n1p335

\begin{abstract}
The article is devoted to problems of perspective industries determination, which are capable to activate innovative potential of the region. The perspective aspect of innovational process intensification, the choice of regional development perspective trends, based on its potential capabilities and resources, as well as particular significance of regional innovative development are substantiated in this article; the perspectives of its development in this course are estimated.
\end{abstract}

Keywords: innovative production, innovative policy of the region, innovative force of attraction, regional economics, method for determination, innovative potential, basic trends in development

\section{Introduction}

In order to implement stated by the Government of Russian Federation long term strategic goal of economy's transferring to innovative state, it is necessary to establish a compound innovational system of developed infrastructure, which will make the market of Russian technological innovations transparent and understandable for all participants of innovational process (The Global Competitiveness Report 2008-2009, Stenography report about meeting of Council of science, technologies and education, 2008). It can be achieved by using of coordinate system in wide sense as arena for innovation process, which includes the system of subjects and their correlations, and by calculating «boiling points of growth». In a context of current paperwork the following definition is provided. The «boiling points» - are large-scale projects, conducted by State, which have a distinguished importance for development of social-economical systems, which can provide technological breakthrough based on interdisciplinary researches and by these means will allow to take leading positions at the world market (Hague et al., 2005).

Currently there are no available possibilities for strategy of technological breakthrough and leadership in wide front of directions and technologies (Kondrashova et al., 2013). During the world economic crisis assignations in economy's real sector were being slightly reduced (Doroshenko, Taburchak, \& Gogua 2013). But there is still a possibility for taking leader positions in accordance with one or several high priorities (Glaziev, 2009).

We see the argumentation about Russia's favorable transfer to the new, 6th, technological structure as correct, but yet not justified enough. It's core meaning rises the statement that trajectory of transfer to new structure has not been formed yet and our country has an opportunity to partake in uprising flow of new long economic growth wave (Gusakov, 2009). All these arguments prove the necessity of innovational manufacturing intensification at regional level as well as at level of national economic system.

\section{Methods}

\subsection{Research of Actuality and Essence of Integrative Collaboration Processes between Participants of Innovative Activity}

Requirement of development and substantiation of approaches to exploration of methodological aspects of scientific problem stipulated by the following circumstances:

In first, transformations become one of the specific characteristics of modern economy. 
In second, the dominating modern world tendency of development is integration, because it includes almost all subjects, which function at different levels of financial-economic activity organization - from household to state economic unions. Nowadays, in a modern world, it is difficult to find such subjects, which do not have economic relations, that is why different levels subjects are involved into integrative collaboration (Bork, 1954).

In third, the innovative aspect of integrative collaboration has an important meaning for modern Russia, because barriers, existing between subjects of innovational process, decrease an investment activity, facilitate the fixing of raw orientation and general inhibition of national economy development, condemn for increasing of unreasonable transaction costs.

In forth, the trend for strengthening of power vertical, gradually maintaining in modern Russia, finds its manifestation in expanding an area and in formation of specific structure of state power management. Alongside, existence of peculiar chain in power structure is authorized by its input in rational allocation of labor force, real integration and acceleration of national economy's innovative development (Williamson, 1995).

In fifth, an objective process of Russia's national economy's innovative compound development occurs. In conditions of innovational dynamic it is necessary to establish the optimal shapes of integrative collaboration between subjects of innovative process and construct the rational economy's structure. It is necessary to note the fact, that any demonstration of disintegration between subjects brings a threat to integrity and to innovation changes in economy, which resources attract many interested subjects of world economy (Vaganova, 2010).

In our point of view, an intensive development of integration collaboration of innovative process subjects allows the participants of that collaboration to enter the brand new level of functioning in environment, allows to reach breakthrough results in science, enables the development of resource base, innovative infrastructure and institutional environment, and also promotes the utilization of new instruments, mechanisms and strategies, aimed at active search of deep changes in cooperative economic systems (Glagolev \& Vaganova, 2013).

Therefore, as intensification of integrative collaboration we understand the process of accelerated development of innovative activity, transfer of all subjects, participating in that process to more active actions. As an economic category intensification reflects quality process of changing the connections and relations between all members of innovative activity and represents in strengthening of innovation activity development's dynamic, in self-implementation of all participants of innovative process, necessity in their self-development and self-perfection.

Due to exceptional importance of process of subjects' integrative collaboration intensification in economic literature much attention pays to issues of intensification, integration and innovations. However, in spite of production, integration and innovation process's intensification issues sufficiently full and versatile covered in special literature, there are arguments concerning the definitions of these conditions.

The word «intensification» itself (in translation from lat. - effort, tension) assumes, that it is allowed to speak about intensification of some factor, considering intensity of its utilization, and about intensification of manufacturing, and alongside it is necessary to diversify intensification of personal and materialistic factors, intensification of collaboration of integrative processes, intensification of innovative process, intensification of fixed and circulating assets, etc. However, it is necessary to note, that, in spite of significant differences between objects we can determine the same characteristics. In all cases there are two principally different ways, methods of solving of some problem: extensive or intensive. In first case, it is merely planting of new product into market, expanding of manufacturing and obtaining the vast result, by using of intensive way we utilize less amount of time, resources and establish favorable environment for achievement of stated goals. These conclusions are supported by famous statement from «The Capital»: that «...from well-known periods of time reproduction occurs, and if examine it from social point of view - reproduction in expanded scale: expanded extensively, if expands only after production; expanded intensively, if the more effective production tools are used» (Marks \& Engels, 1867).

As mentioned above, one of intensification's definitions in increasing of tension, concentration of some process. Under intensification we understand a process of reducing of time for acceleration of innovative process and innovations implementation due to transfer to more active actions of all subjects, which participate in that process. It is all luckily correlates with economic category of integrative collaboration, which reflects the process of changes of connections and relations between all participants of innovative activity. As a rule, much intensive, concentrated flow of innovative process provides the more rapid implementation of product into market and, as a consequence, the increasing in competitiveness of separate industrial complexes. 


\subsection{Creation of Mechanism for Strategy of Innovative Process Intensification}

Core question of intensification of innovational process in region is development of approach for elaboration strategy of innovational transfer based on priorities determination. Scientific literature proposes three basic options of innovational development strategy:

- Technological breakthrough based on domestic inventions and developments;

- Transfer of technologies/ borrowing of technologies (e.g. in Japan, countries of South-Eastern Asia), when personal domestic technological developments, new technologies and new production outcome are based on utilizing of obtained foreign patents (strategy of pursuit);

- Participation in manufacturing of new products (assembly and other types of manufacturing) (Polterovich, 2008).

However, it can't be definitely stated that this or that option would be sufficient for elaboration of region's innovation development, that is why it would be rational to use a mixed strategy of innovational development (Kline \& Rosenberg, 1986). Such mixed innovational strategy is based on the following statements:

- Local technological breakthrough at set of technologies based on domestic inventions and developments;

- Transfer of technologies with account of domestic scientific developments;

- Establishment of joint manufactures based on high-tech re-equipment of enterprises.

Implementation of innovational strategy and its individual directions depends on the set of factors, which can be viewed as hypothesizes demanding an additional research. Alongside specification of favorable transfer period, the following management mechanisms can be referred to new technological structure:

- Management mechanism for intensification of innovational production and formation of region's innovational development structures;

- Regional economy segmentation from the position of breakthrough technology maintenance;

- Establishment of regional system of personnel preparation for innovational manufacturing;

- Financial mechanisms for maintenance of innovational production intensification (Doroshenko, Somina, \& Komissarov, 2013).

Considering the chosen innovational strategy it is necessary to define the position about prior policy in science and technologies area (Scientific-technological forecast - an important element of Russia's development strategy, 2009). In recent times Russian scientists have been intensively developing a scientific-technological forecast, called to determine the ways of country's technological gap overcoming and real priorities of technological development (Chizhova, 2012).

Considering the current condition of Russia's economy, we can propose the system of measures for allocation of priorities of technological development in purposes of economic and technological policy's renewal. Moving in these directions assumes the strategic selection of long-term and the most effective options for development of regional social-economic systems under the State administration, which will guarantee the leading positions and competitiveness of region.

An effective work for forming of effective mechanisms of strategic economy development proposes the development of national program, and for the rest - national projects.

The diversity of tasks, which have to be solved in process of economy's innovational development «boiling points» determination, can be narrowed to a single purpose - maintaining of maximal accuracy and opportunity for correction of parameters in dependence of macroeconomic conditions scenarios. The principal scheme of works organization for determination of «boiling points» of innovational development represented at figure 1.

A direct operation on determination of innovational development «boiling points» is rather difficult process and is regulated by federal and regional laws. First stage represents the development and determination of priority directions of region's innovation development and their adaptations to federal scenarios of national innovational system development conditions.

Essence of the second stage is in receiving of preliminarily result, i.e. the forecast estimations of core indicators of region's innovational potential.

At the final stage main directions of region's innovational development are specified and corrected and after that innovational process's forecast indicators are specified. According to Federal Law from 20.07.1995 № 115-FL 
the forecast estimations are provided to State Duma, and determined «points» of innovational development, which were determined, are provided to Russia's Ministry of Economy.

The core directions of economy's innovational development are represented in a report form and represented to legislative department of Russia's state authorities.



Figure 1. The principal scheme of work organization for determination of «boiling points» of economy's innovational development

\subsection{Definition of Principles and Methods of Region's Innovative Production "Boiling Points" Determination} An effective work of mechanisms of region's innovative manufacturing «boiling points» determination demands the usage of various analytical methods: forecasting, planning, expertise and monitoring, with involvement of many experts from scientific community. Considering a permanently growing meaning of punctual selection of innovational production management, development of such events in methodological aspect must foresee the following core principles: 
- The complexity - system of selection of innovational manufacturing «boiling points» must embrace the whole specter of regional development and life sustenance;

- $\quad$ Consistency, which, from one side, presumes a necessity of regional economy defining as a part of national innovational system, and from other side - as a system, consisted from complicated set of interconnected object of regional level;

- Alternativeness, maintaining of which increases the reliability of «boiling points» determination process, and also stimulates the basing of concept of interregional and foreign-economic connections;

- Multi-variant approach in goals statement as well as in choosing the ways of terms of their achievement;

- Programmable approach expressed in connection of purposes and demanded resources with region's financial possibilities, with considering of probable involvement of off-budget financial sources;

- Comparability of forecast indicators of region's innovational manufacturing «boiling points» at vertical of region's innovational potential objects;

- Combinationness (multilevelness) of mechanisms of innovation production management, which by essential way maintains an increasing of receiving evaluations of «boiling points» sustainability in region's innovational development; is described by vast amount indicators, therefore it is practicable to use multi-stage calculation scheme;

Multiversity of tasks, which has to be solved during determination of boiling points of region's innovational development, can be brought together to a single purpose - maintenance of maximal accuracy and possibility of parameters correction in dependence of scenario macro-economic conditions.

Determination of main directions of innovational development and allocation of «boiling points» of regional innovational manufacturing is not just a complex, but labor-intensive process, which includes an explanation of paces and dynamic of innovational manufacturing development. Therefore it is necessary to be oriented not just at methods of direct calculation, but also at usage of mathematical apparatus (Kline \& Rosenberg, 1986).

Among the diversity of selection methods ofdirections and forecasting of innovational potential development it is possible to define the following groups of them:

Formalized methods. They include various methods of extrapolation, regressive and adaptive models. Usage of simple extrapolation and extrapolation for receiving of estimation of innovational potential development based on implementation of innovational development directions in «boiling points» of regional production is highly limited, because usually there are no sustainable development tendencies in the regions. Therefore the indicator's linear growth changes to non-linear and vice versa.

Intuitive methods include: expert estimation and also the method of Delphi (Davnis \& Zelentsova, 2005), which determines qualitative components of region's innovation development evaluation.

Combined methods include adaptive-rational models, and models with usage of linear programming principle.

Methods analysis demonstrates that most part of it has a limited amount of applicability. By analyzing the reasons of that it is possible to single out three main problems: the complexity of method's practical implementation; inadequacy to the specific of forecasting processes, which describes region's innovational development; increased requirements to informational maintenance. Only the first of these reasons can be overcome by creation of appropriate software. Two other reasons are interconnected with each other: during the calculation of statistically sustainable models it is necessary to use sample sets of sufficiently huge volumes (Blanchet-Scalliet et al., 2008). The modern development dynamic of innovational manufacturing in regions does not allow to form a unimodal sets of appropriate volumes for these purposes.

\subsection{Technique}

The analysis of abovementioned modelling problems, and specifically indeterminacy of functioning conditions of region's innovational development, and also multidimensionality of evaluated processes in current area, brings us the necessity to utilize the method of linear-adaptive programming for determination of «boiling points» of region's innovational manufacturing (figure 2).

An essential condition for staging and implementation of linear programming purposes are determination of limitations for resource component of regional innovational production, the amount of demand and criteria of optimal indicator of region's innovational development. 




Figure 2. Development of combined method of determination of region's innovational manufacturing «boiling points»

In our approach to determination of «boiling points» of region's innovational manufacturing was utilized the information which is included in custom regional statistical brochures, which compound data about outcome of innovational products, quantity of personnel in $\mathrm{R} \& \mathrm{D}$, about volumes of production funds by economic activity terms.

The first stage of research was a model representation of correlation between the elements of regional economy. Particularly, the production functions of Cobb-Douglass were made for each type of region's economic activity, on basis of which was created the following function:

$$
\alpha_{i}=\frac{F_{2_{i}}}{F_{1_{i}}} 100 \%-100 \%
$$

where $\alpha$ - rate of main production assets increase (\%); $F_{2_{i}}, F_{1_{i}}$ - basic assets of innovational activity in planned and basis terms accordingly.

In changing of basic production assets cost for $\alpha$ [\%], volumes of innovational manufacturing can be calculated by equation:

$$
x_{2_{i}}=x_{1_{i}}+\frac{\alpha_{i} \beta_{i}}{100 \%} x_{1_{i}}
$$

where $x_{2_{i}} x_{1_{i}}$ - the volume of production per each kind of innovational activity (accordingly, in planned and basis terms); $\beta$ - an indicator of production outcome elasticity by production assets.; 
Or after substitution of (1) into (2) planned volume of innovational manufacturing can be calculated by formula:

$$
x_{2_{i}}=x_{1_{i}}+\frac{\beta_{i} \cdot\left(\frac{F_{2_{i}}}{F_{1_{i}}}-1\right) \cdot 100 \%}{100 \%} x_{1_{i}}=x_{1_{i}}+\beta_{i} \cdot\left(\frac{F_{2_{i}}}{F_{1_{i}}}-1\right) \cdot x_{1_{i}}=x_{1_{i}}+\frac{F_{2_{i}}}{F_{1_{i}}} \cdot \beta_{i} \cdot x_{1_{i}}-\beta_{i} \cdot x_{1_{i}}
$$

After reorganization formula (3) will have the following interpretation:

$$
x_{2_{i}}=\left(1-\beta_{i}\right) \cdot x_{1_{i}}+\frac{F_{2_{i}}}{F_{1_{i}}} \cdot \beta_{i} \cdot x_{1_{i}}
$$

Gross regional production $(\mathrm{X})$ is calculated by sum of production outcomes by types of economic activity:

$$
X=\sum_{i=1}^{n} x_{2_{i}}
$$

From (4) and (5) the targeted function for calculation of region's economy development will be calculated:

$$
X=\sum_{i=1}^{n} x_{2_{i}}\left(\left(1-\beta_{i}\right) \cdot x_{1_{i}}+\frac{F_{2_{i}}}{F_{1_{i}}} \cdot \beta \cdot x_{1_{i}}\right) \longrightarrow \mathbf{m a x}
$$

At the second stage of research we propose to make an individual territorial scientific-industrial unit, which can support the implementation of «boiling points» in region. In general this integrated structure represents a stable group of companies, united on basis of voluntarily passing the share of wrights to one of participants - the central company of integrated structure «Center», based on the basis of leading university, which conducts the researches of nano-technological environment (pic.3).

Formation of provide unit is represented as highly perspective, because allow in full measure to use the advantages of synergy effect of unity in economy (including the productive, scientific, trading and financial areas) and by that increasing the competitiveness of Russia in global scale.

\section{Results}

In simple option in content of suggested separate territorial scientifically-industrial unit can be included largeand medium-scale, as well as small enterprises of manufacturing from Belgorod region and Belgorod state technological university n.a. V. G. Shukhov (BSTU) as a core regional supplier of innovative scientific developments and high-qualified personnel for industries.

An important aspect of successful activity of industrial enterprises in Belgorod region, which included into separate territorial scientifically-industrial unit, is a possibility to use side technical and labor reserves at the stage of nano-technologies development.

In table 1 are represented the variable indicators and approximate list of actions, execution of which will allow reaching the demanded level of indicator and considering all consequences of such changes.

In table 2 options for development of manufacturing industry are represented. As basis for calculations we used figures by type of economic activity «Processing manufacturing» (Annual statistic report of Belgorod region, 2010) as one from successfully functioning and have relation to national nano-technological network, however, that choice is not principal.

By analyzing of figures from table 2 we can make a conclusion, that undoubtedly leaders are options of industry's development with number 4,5,6. In order to make an unambiguous decision for the most favorable option of industry changes in result of establishment of separate territorial scientifically-industrialunit we used the graphical estimation method of decision options by various criterions (Bukhonova et al., 2009). Transfer of research criterions in extendable characteristics was implemented according table 3 (Eliseeva \& Egorova, 2004).

By each of abovementioned options satisfying the criterions-requirements, at the according scales were pointed figures of estimation indicators, which was transferred to extendable characteristics (table 4). Received points at polar diagram by each option of plan were connected by circled line - polygon (pic.4). Polygon, which has the biggest square, accords to the best option of economy development. 


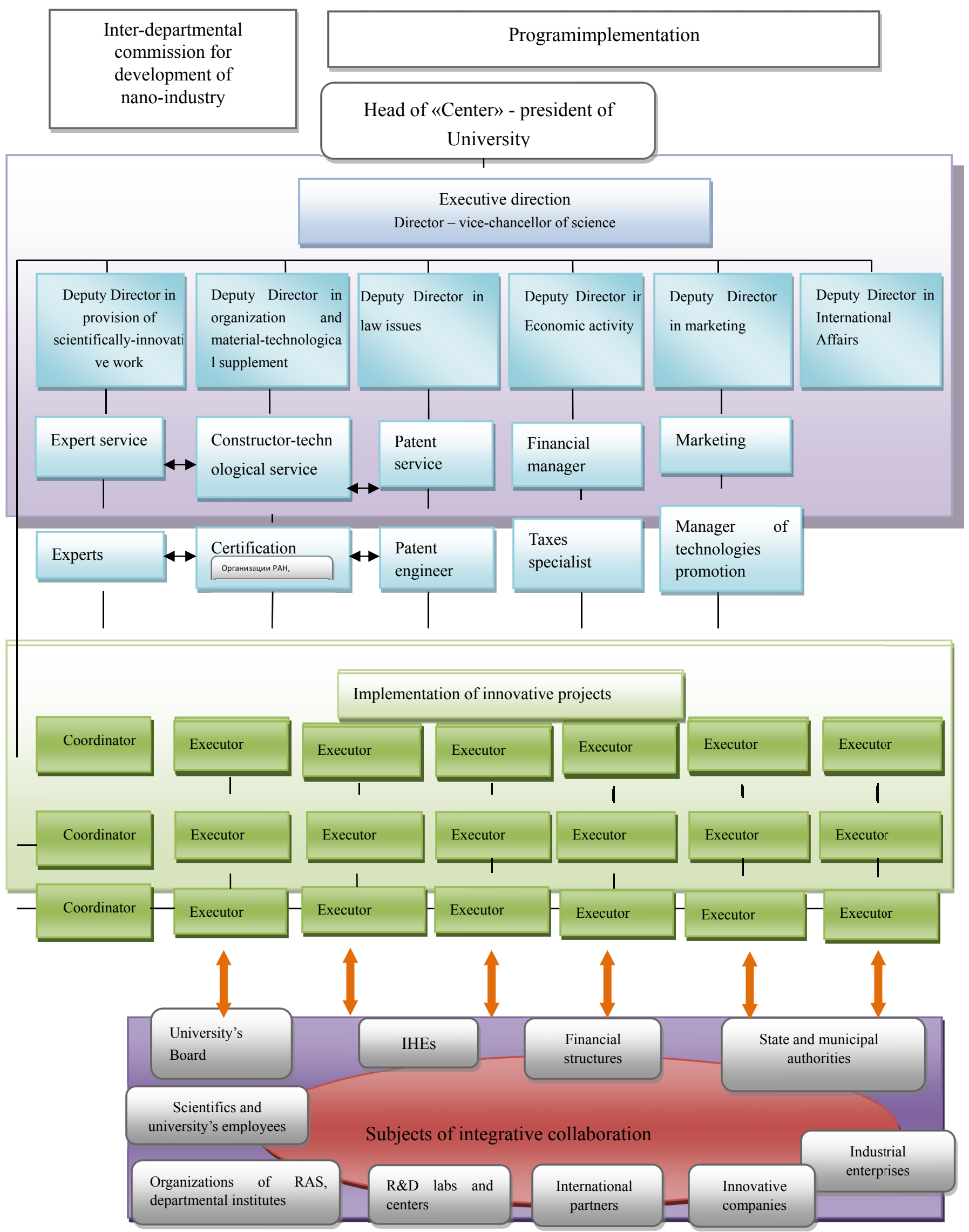

Figure 3. Functional structure of separate territorial scientifically-industrial unit 
Table 1. Variable action parameters and options of their changes

\begin{tabular}{|c|c|c|}
\hline $\begin{array}{l}\text { Variable parameter, } \\
\text { factor }\end{array}$ & Actions & Consequences \\
\hline $\begin{array}{l}\text { 1. Reduction of } \\
\text { average cost of basic } \\
\text { production assets } \\
\text { (BPA) per year }\end{array}$ & $\begin{array}{l}\text { Discarding (selling possible) of equipment, which } \\
\text { is used in R\&D sector, because researches will be } \\
\text { implemented on basis of university }\end{array}$ & $\begin{array}{c}\text { Reduction of cost for maintenance } \\
\text { of BPA discarded part. } \\
\text { Increase of capital productivity } \\
\text { (CP) }\end{array}$ \\
\hline $\begin{array}{l}\text { 2. Reduction of spent } \\
\text { man-days }\end{array}$ & $\begin{array}{c}\text { Elimination of scientific-constructing bureau. } \\
\text { Implementation of research developments by } \\
\text { sciences of university, not by enterprises } \\
\text { employees }\end{array}$ & $\begin{array}{c}\text { Increase of productivity, reduction } \\
\text { of production cost due to absence } \\
\text { of article for cost of wage payment } \\
\text { to personnel of R\&D labs. } \\
\text { Increase of capital-labor ratio } \\
\text { (CLR) }\end{array}$ \\
\hline $\begin{array}{l}\text { 3. Increase in cost of } \\
\text { products }\end{array}$ & $\begin{array}{l}\text { Reduction of production cost due to variation of } \\
\text { factors (1) and (2), increasing of products cost by } \\
\text { increasing its innovative characteristics }\end{array}$ & $\begin{array}{l}\text { Increase of products profitability } \\
\text { (PP) } \\
\text { Increase of enterprises profitability } \\
\text { Increase of payment costs for } \\
\text { scientists in BSTU. }\end{array}$ \\
\hline $\begin{array}{l}\text { 4. Increase of } \\
\text { high-tech production } \\
\text { output by region's } \\
\text { enterprises }\end{array}$ & $\begin{array}{l}\text { Mastering of new types of products, involvement } \\
\text { of region's young scientists into development of } \\
\text { innovative technologies. Modernization of } \\
\text { production technological schemes }\end{array}$ & $\begin{array}{l}\text { Increase of innovative goods } \\
\text { amount (IG) } \\
\text { Increase of GRP }\end{array}$ \\
\hline
\end{tabular}

Table 2. Options for changes in industry in result of establishment of separate territorial scientifically-industrial unit

\begin{tabular}{l}
\multicolumn{1}{c}{ Criterions } \\
Options
\end{tabular}

Table 3. Accordance of criterions amounts to extendable characteristics

\begin{tabular}{|c|c|c|c|c|c|c|c|c|c|}
\hline \multicolumn{2}{|c|}{ Criterion 1-CP } & \multicolumn{2}{|l|}{ Criterion 2-CLR } & \multicolumn{2}{|l|}{ Criterion 3-LE } & \multicolumn{2}{|c|}{ Criterion 4-PP } & \multicolumn{2}{|l|}{ Criterion 5-IG } \\
\hline Scale & & Scale for CLR & & Scale for LE & & Scale for & & Scale for IG & \\
\hline $\mathrm{CP}$ & 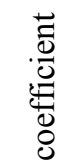 & & 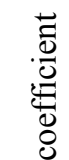 & & $\begin{array}{l}\overrightarrow{0} \\
\stackrel{0}{0} \\
\stackrel{0}{0} \\
0 \\
0\end{array}$ & PP & 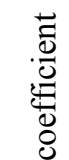 & &  \\
\hline $\mathrm{CP}<1,4$ & 0 & $\mathrm{CLR}<70$ & 0 & $\mathrm{LE}<560$ & 0 & $\mathrm{PP}<3$ & 0 & $\mathrm{IG}<455$ & 0 \\
\hline $1,4 \leq \mathrm{CP}<2,8$ & 1 & $70 \leq \mathrm{CLR}<141$ & 1 & $560 \leq \mathrm{LE}<1120$ & 1 & $3 \leq \mathrm{PP}<7$ & 1 & $455 \leq \mathrm{IG}<910$ & 1 \\
\hline $2,8 \leq \mathrm{CP}<4,2$ & 2 & $141 \leq \mathrm{CLR}<212$ & 2 & $1120 \leq \mathrm{LE}<1680$ & 2 & $7 \leq \mathrm{PP}<10$ & 2 & $910 \leq \mathrm{IG}<1370$ & 2 \\
\hline $4,2 \leq \mathrm{CP}$ & 3 & $212 \leq \mathrm{CLR}$ & 3 & $1680 \leq \mathrm{LE}$ & 3 & $10 \leq \mathrm{PP}$ & 3 & $1370 \leq \mathrm{IG}$ & 3 \\
\hline
\end{tabular}


Table 4. Figures of estimation indicators

\begin{tabular}{ccccccc}
\hline Criterions & \multicolumn{7}{c}{ Options of changes } \\
\cline { 2 - 6 } & 1 & 2 & 3 & 4 & 5 & 6 \\
\hline Capital productivity (CP) & 2 & 2 & 2 & 3 & 2 & 3 \\
Capital-labor ratio (CLR) & 2 & 3 & 2 & 2 & 2 & 2 \\
Labor efficiency (LE) & 2 & 2 & 2 & 3 & 2 & 3 \\
Products profitability (PP) & 2 & 2 & 2 & 3 & 2 & 3 \\
Amount of innovation goods (IG) & 2 & 2 & 2 & 2 & 3 & 3 \\
Polygon square & 9,5 & 12,0 & 9,5 & 16,87 & 12,0 & 19,11 \\
\hline
\end{tabular}


Figure 4. The alternatives polygon of industrial complex development

In result of conducted analysis we can affirm that undoubtedly best option of development is an option № 6 . Provided calculations prove the efficiency of establishment of territorial scientifically-industrial unit, which will provide powerful financial inflow into regional budget's profit part.

Suggested integrative structure will maintain the changes of traditional educational forms, IHEs employees, post-graduates and doctorates on contract basis will be occupied by R\&D work, there will be more opportunities at production sites, alongside we forecast the growth of innovative products manufacturing by $10 \%$ and, accordingly, increase of products cost by $10 \%$.

Suggested amount of positive effect from establishment of unit in area of economic activity «Processing manufacturing» represented in table 5 .

Table 5. The amount of positive effect as a result of establishment of territorial scientifically-industrial unit

\begin{tabular}{cccc}
\hline & Basic development option & Enhanced development option & Pace of indicator growth \\
\hline Assets potential & 0,71 & 0,92 & 1,29 \\
Labor potential & 0,70 & 0,98 & 1,40 \\
Financial potential & 0,52 & 0,56 & 1,08 \\
Innovative potential & 0,82 & 0,90 & 1,09 \\
Gross regional product & 0,60 & 0,60 & 1,00 \\
\hline
\end{tabular}

Alongside the development of innovational process on basis of territorial scientifically-industrial unit will lead to the expansion of scales of gross regional product. Current statement can be approved by calculations using the formula (6).

\section{Discussion}

All these calculations have an applied orientation, i.e. can be applied for determination of efficiency of territorial scientifically-industrial unit functioning, indicators of functioningmust be reflected in conditions of state contract. 
For instance, after project implementation its executors have to provide the further: annual n-multiple increase in sale volume of created new and modernized high-tech products in reliance to budged funds spent on project; patent the results of intellectual activity, obtained during project's implementation; increase of quantity of workplaces for high-qualified workers.

\section{Summary}

1. Researches demonstrate that gradually on territorial level occurs the process of management of scientifically-technical development of industrial manufacturing. This process is difficult. Difficulties are explained by practically full absence of innovative process management methodology, hard disposable planning-functional gaps in innovative process on multiple-industrial «joints» during issue solving of main production chain, unsufficient readiness of power authorities to integrative cooperation with real sector of economy and R\&D sectors. For activation of that process it is necessary to establish a territorial scientifically-industrial unit, which will be an innovative complex and organizational and methodological form of such occurrence implementation, as integrative collaboration between subjects of innovative process.

2. Modern stage of Russia's economy development demands the settlement of important issue of domestic enterprises' competitiveness increase, their plugging in global chains of added value not just as raw materials suppliers, but as high-tech products manufacturing. With that purpose in current paperwork were defined the approaches to determination of «boiling points», where Russia can expect the strengthening of positions by using of its competitive advantages.

3. The results of research demonstrate that Belgorod region has a significant scientifically-technical potential in field of nano-technologies, which allows expecting increase of its input into innovative development of national economy. However, the amount and terms of innovative development's purposes achievement will depend on the measure of integrative collaboration between key participants of that process.

\section{Acknowledgements}

The article was published with the financial support from Ministry of Education and Science of the Russian Federation within the framework of state assignment to the project \#26.1511.2014K "Theory and methodology of managing innovational and investment processes in small business enterprises."

\section{References}

Annual statistic report of Belgorod region. (2010). Governmental statistic comittee of Belgorod region (p. 224).

Blanchet-Scalliet, C., Karoui, N. El, Jeanblanc, M., \& Martellini, L. (2008). Optimal investment decisions when time-horizon is uncertain. Journal of Mathematical Economics, 44(11), 1100-1113. http://dx.doi.org/10.1016/j.jmateco.2007.09.004

Bork, R. H. (1954). Vertical integration and the Sherman Act: The legal history of economic misconception. University of Chicago Law Review, 22, 157-201. http://dx.doi.org/10.2307/1598229

Brockhoff, K. (1994). Forschung und Entwicklung Planung und kontrolle. München.

Bukhonova, S. M., Doroshenko, Y. A., Slabinskaya, I. A., \& Chikina, E. D. (2009). Estimation and management of sustainable enetrprise development. Saint-Petersburg: Khimizdat.

Chizhova, E. N. (2012). Analysis of enterprise's innovative system structure. Vestnik BUKEP, 1, 185-193.

Davnis, V. V., \& Zelentsova, S. Y. (2005). Application of matrix predictor in issues of imitational modelling of region's economic development indicators. Theoretical basis and experience of strategical management of territories planning, Voronezh State University, 193-197.

Doroshenko, Yu. A., Somina, I. V., \& Komissarov, S. A. (2013). Sources of Financing and Innovative and Investment Activity of Small Enterprises. World Applied Sciences Journal, 25(6), 975-982. http://www.idosi.org/wasj/wasj25(6)13/23.pdf

Doroshenko, Yu. A., Taburchak, A. P., \& Gogua, L. S. (2013). Financial Management of High-Technology Innovation Enterprises. Middle-East Journal of Scientific Research, 17(9), 1327-1336. http://www.idosi.org/mejsr/mejsr17(9)13/18.pdf

Eliseeva, I. I., \& Egorova, I. I. (2004). Statistics: The textbook. Moscow: Prospect.

Glagolev, S. N., \& Vaganova, O. V. (2013). Specific Determinants for structuring the Economy, Taking into Account the Factor of Integration. World Applied Sciences Journal, 24(10), 1322-1329. http://www.idosi.org/wasj/wasj24(10)13/8.pdf 
Glaziev, S. Y. (2009). World economic crisis as a process of technological structures shifting. EconomicIssues.

Gusakov, M. A. (2009). Modernization of scientific-innovational process. Economics and Management, 10(48).

Hague, R., Harrop, M., \& Breslin, S. (2005). Comparative government and politics an introduction. Macmillan.

Kline, S. \& Rosenberg, N. (1986). An Overview of Innovation. The Positive Sum Strategy. Landau and Rosenberg (Eds.). Washington.

Kondrashova, E. A., Taburchak, A. P., \& Lebedev, O. V. (2013). Innovation Growth of Russia: Budget Limits. World Applied Sciences Journal, 24(12), 1662-1668. Retrieved from http://www.idosi.org/wasj/wasj24(12) 13/17.pdf

Marks, K., \& Engels, F. (1867). Criticism of political economy: T1. Book 1: Process of capital production (2nd ed., p. 337).

Polterovich, V. (2008). Principles of national innovational system formation. Issues of management theory and practice, 11.

Scientific-technological forecast - an important element of Russia's development strategy. Diaries of scientific session of RAS general meeting. (2009). Bulletin of Russia's academy of sciences, 79(3).

Stenography report about meeting of Council of science, technologies and education. (2008). Innovations, 111(1).

The Global Competitiveness Report 2008-2009. World Economic Forum.

Vaganova, O. V. (2010). Methods of innovative production "boiling points" determination. Microeconomics, 5 , 11-16.

Williamson, O. E. (1995). Veritcal manufacturing integration: Thoughts about market failures. Company theory, $2,33-53$.

\section{Copyrights}

Copyright for this article is retained by the author(s), with first publication rights granted to the journal.

This is an open-access article distributed under the terms and conditions of the Creative Commons Attribution license (http://creativecommons.org/licenses/by/3.0/). 